\title{
Mycoflora Associated with Green Gram Seeds in Odisha and their Effect on Seed Health
}

\author{
Sandhyarani Nanda*, M. K. Mishra and Tensirani Pradhan, \\ Biswajit Jena and Lipilipsa Priyadarshinee
} Department of Plant Pathology, Odisha University of Agriculture and Technology,
Bhubaneswar, 756003, Odisha, India

*Corresponding author

\begin{abstract}
A B S T R A C T
Keywords

Mycoflora,

Green gram seed, seed health

Article Info

Accepted:

05 April 2020

Available Online:

10 May 2020

Green gram is used as one of the important source of protein along with other pulses. The potential yield is affected by many seed borne pathogen. Stored and freshly harvested green gram seeds from different places of Odisha were collected to study the association of different fungal pathogen. Five fungal pathogens i.e. Aspergillus niger, Aspergillus flavus, Fusarium sp, Rhizoctonia $s p$ and a sterile mycelium were found to be associated with seeds. Germination was lower in seeds with higher fungal infection than in seeds with lower infection in both freshly harvested and stored seeds. Surface sterilization reduced fungal infection and improved germination. Highest germination percent $(88.0 \%)$ and lowest infection $(12.5 \%)$ were found in surface sterilized greengram seeds collected from stored condition and germination percentage of $84 \%$ with $14.5 \%$ infection rate was found in seeds collected from field of Sinapali, Nuapada, Odisha. Highest healthy seed $(84.25 \%)$ was observed in Sinapali, Nuapada, seed sample and lowest $(54.25 \%)$ was found in Bhadrak seed sample. Healthy seeds inoculated by casual pathogen showed reduced germination and other quality parameter. Maximum reduction in germination $(32.95 \%)$ and seedling vigour index $(50.88 \%)$ was. caused by Aspergillus flavus. Seed rot was highest by Aspergillus niger (25.25\%).
\end{abstract}

\section{Introduction}

Green gram (Vigna radiata (L.) R. Wilczek) alternatively known as the mung bean, Maash, moong or mudga is a plant species in fabaceae family used as source of protein worldwide. The potential yield of green gram is greatly influenced by a number of foliar and soil borne diseases out of which majority are seed borne. The pathogen attack all parts of plant i.e. root, stem, branches, petioles, leaves, pods and seeds. Moreover, seed infection of Rhizoctonia bataticola. (Macrophomina phaseolina) ranges from 2. $2-15.7 \%$ which causes $10.8 \%$ loss in grain yield and $12.3 \%$ loss in protein content of 
seed in mungbean (Kaushik et al., 1987). The infected seeds act as an important source of primary inoculum for news areas. Seeds are efficient means for survival, large scale and long distance spread of pathogenic organism. Pathogen can be present in seeds both externally as well as internally. Infected or contaminated seeds are hazardous for seed lots as they can cause pre and post emergence losses and finally resulting in reduced germination of seeds, reduction of yield and also spoiling the quality of seeds during storage. A perfect seed health evaluation not only helps in preventing the spread of pathogen/microorganisms but also helps in smooth functioning of seeds. The present investigations were conducted on detection, identification, estimation of mycoflora associated with green gram seeds collected from different parts of Odisha. The experiment was conducted to assess the association of various seed born epathogen and their effect on seed germination and seedling vigour in the Plant Pathology Department, College of Agriculture, Odisha University of Agriculture and Technology, Bhubaneswar, Odisha.

\section{Materials and Methods}

\section{Collection of seed sample}

A total of 25 seed samples were collected from different places of Bhubaneswar, Bhadrak, Junagarh, Bhawanipatna, Titlagarh and Sinapali (Nuapada) of Odisha. Both stored and freshly harvested seeds were collected during the month of June and July 2018. Samples from each place were collected randomly according to International seed testing association (1976) rules. Each sample was about $0.5 \mathrm{~kg}$. The samples were enclosed in polythene bags with proper labeling, brought directly to laboratory and kept in the refrigerator at $5 \pm 1^{\circ} \mathrm{c}$ until used for subsequent studies.
Several methods of seed health testing have been used for the detection of fungi (Neergard, 1977).

\section{Examination of seeds without incubation}

\section{Dry seed examination}

Green gram seeds collected from above sources were observed for different grade of discoloration and percent disease incidence was calculated. Spores and other fungal bodies like sclerotia, galls, acervuli, pycnidia, perithecia, hyphae, spore masses etc were recorded.

\section{Seed washing test}

Washing test was performed to detect and identify the spores adhering on seed surfaces. Two grams of seed from working sample was taken in $10 \mathrm{ml}$ of sterile distilled water and was shaken for 10 minutes in a mechanical shaker to remove the adhering parts of organism from the seeds. Some amounts of suspended spores were concentrated by centrifuging at 3000rpm for 15-20 minutes.

\section{Examination and isolation of seed mycoflora under incubation}

\section{Standard Blotter method}

Two blottrer papers after soaking in sterile water were kept on each other to form a layer at the bottom of ninety $\mathrm{mm}$ petridishes. In each plate 10 seeds were placed on the moistened blotters in such a manner that nine formed on the outer circle and one at the center. For each sample 40 replicated plates were maintained (total 400 seeds tested in each sample). The plates were incubated at $22 \pm 2^{\circ} \mathrm{c}$ for 7 days in alternating cycles of 12 hours darkness and 12 hours light. The incubated seeds were examined after seven days under a stereo binocular microscope to 
record the incidence of different seed borne fungi. Fungal growths on the seeds were aseptically mounted in lactophenol blue and were examined under a compound microscope for further study.

\section{Agar plate method}

Antibiotic rich Potato dextrose agar (15-20ml) was poured in each sterilized petriplate. Seeds of each sample were surface sterilized with $2.0 \%$ sodium hypochlorite for 30 seconds followed by washing twice with sterile distilled water thoroughly. Nine seeds were placed on outer circle and one at the center in previously poured medium. 10 replication for each sample was maintained and incubated for 5-7 days at $22-25^{\circ} \mathrm{C}$ under $12 \mathrm{~h}$ alternating cycles of darkness and $12 \mathrm{~h}$ light.

\section{Rolled paper towel method}

Two paper towels of good quality were soaked in sterile water and excess water drained off. A total of 100 seeds were randomly taken from each sample and kept equally. The towels were rolled gently and ends were closed with rubber bands. Four replications were maintained for each sample. The seeds were incubated at $30 \pm 2^{\circ} \mathrm{c}$ for 14 days. First observation was taken after 5 days and final count was taken after 14days of incubation period pertaining to (a) \%germination (b) non-germinated seed (hard seed and rotten seed) (c) shoot length (d) Root length (e) Vigour index and incidence of seed mycoflora.

\section{Purification and identification of the isolated pathogen}

The pure cultures of the fungi were obtained by culturing the fungus on Potato dextrose agar medium from 'hyphal tip' of actively growing colony under aseptic conditions. Pure cultures of fungi were identified on the basis of their mycelial growth, colony characters, colour, growth habit, and according to available literature. One purified fungus was sent to Indian Type Culture Collection Centre, Indian Agriculture Research Institute (IARI), New Delhi for identification.

\section{Pathogenicity}

Apparently healthy seeds without any visible symptoms were separated from the seed lots. The seeds were surface sterilized by dipping the seeds in $2 \%$ sodium hypochlorite solution for 3 minute followed by washing 4-5 times in distilled sterile water. Seeds were soaked for four hours in spore suspension of isolated pathogen separately. Then the seeds were rolled on sterilized blotter of $8.5 \mathrm{~cm}$ diameter and then left in sterilized petri dishes for drying overnight. The inoculated seeds were used for different test such as(a) Germination test (b) non-germinated seeds(hard seeds and rotted seeds) (c) Seedling vigour index(d)seedling symptom test. For germination and seedling vigour test standard blotter and rolled towel method was used. Test tube agar method was used for seedling symptom test and pot culture method was used for speed of germination.

\section{Results and Discussion}

\section{Germination test}

The seed samples collected from different places were first tested for their germ inability under surface sterilization and without sterilization. Higher germination percentage was found in the surface sterilized green gram seed collected from both stored and field condition. Highest germination percent $(88.0 \%)$ and lowest infection $(12.5 \%)$ were found in green gram seeds collected from Sinapali, Nuapada from store seed and germination percentage of $84 \%$ with $14.5 \%$ 
infection was found in seeds from field condition. It was observed that seed borne pathogen were more associated with seeds collected from field with reduced germination rate and more infection percentage (Table $1 \&$ 2).

\section{Evaluation of seed health}

The collected seeds were evaluated for their association of different microorganism, colour, shape and other mixture seeds by dry seed method, seed washing method, standard blotter method, agar plate and rolled paper towel method. Highest healthy seeds were recorded from seeds collected from Sinapali $(84.25 \%)$ followed by Bhawanipatna $(83.25 \%)$. Titlagarh seed was found to have maximum shrunken seeds $(9.50 \%$, Table 3$)$.

\section{Mycoflora associated with green gram seeds}

The external and internal seed borne pathogen were evaluated by standard blotter, agar plate method and rolled paper towel method., Fusarium sp, Aspergillus flavus, Aspergillus niger, Rhizoctonia sp and a sterile mycelium were invariably found in all the green gram seeds collected from all the places. Fungal colonies grown out of different green gram seeds were microscopically observed for different structures and spores. The fungal colonies were isolated and grown in fresh Potato dextrose agar (PDA) plates. Fungal tips from the periphery of the actively growing colonies were purified and observed for their microscopic structures. The detailed morphology are described below.

\section{Fusarium sp.}

Growth of Fusarium on PDA was dull white to slightly dark towards the periphery and covered the entire plate in seven days. The colour of the mycelium was orange to pink at back side of the PDA plate. The mycelia was hyaline septate, conidiophores were single and lateral. Conidia were hyaline tapering towards both ends widest in the middle, 3-4 septa, and measured in $20-52 \times 3-4 \mu \mathrm{m}$.

Microconidia were abundant, mostly non septate, straight or curved measuring $5-10 \times 2$. 1-3.2 $\mu \mathrm{m}$. The fungus was tentatively identified as Fusarium sp by following available literature.

\section{Aspergillus flavus}

The growth of the fungus on PDA was greenish yellow with whitish mycelial tips at the periphery. The fungus was very fast growing touching $80 \mathrm{~mm}$ in fourth day in petriplate. Conidiophores arised separately from the substratum broadening upwards and one vescicle was found at the tip and measured 42.8 to $56.23 \mu \mathrm{m}$ in diameter. Phialides were present and conidia globose hyaline to yellowish green. Usually spinulose and sometimes smooth and measured 2.5 to $5.2 \mu \mathrm{m}$ in size. The fungus was identified as Aspergillusflavus with reference to available literature.

\section{Aspergillus niger}

Colonies on PDA were first dull white gradually converted to black due to sporulation of the fungus. The growth was very fast and covered the entire plate within four days. Mycelium was submerged hyaline, septate and branched. Conidiophores were hyaline arising from the substratum non septate but occasionally with septa with variable length measuring $8-10 \mu \mathrm{m}$. One vescicle was found at the tip of the conidiophore which was round to globose with $60-85 \mu \mathrm{m}$ in diameter. Phialides were found on the vesicle and conidia in chain. The fungus was identified as Aspergilus niger. 


\section{Rhizoctonia sp}

The growth of the fungus was initially white with aerial mycelium. Dense white mycelium was found at the center and faint mycelial growth found towards the periphery with small whitish beads towards periphery. The fungus grew small brown rounded sclerotia at 15 days of growth of breadth. The mycelial strands were found at right angles and measured. The fungus was identified as Rhizoctonia sp.

\section{Sterile mycelium}

Whitish growth was observed on the PDA plates and the fungus covered entire plate in 8 days. The mycelium was sparsh, radial in nature with dense white growth towards the periphery of the plate. The colour of the fungus turns to light orange at the 12days of growth. Long strands of mycelial growth with interwoven in nature were found without any septa.

The mycelium was hyaline with clumpsy and netted appearance. As the fungus grew in plates there were no sporulations or sclerotial growth found on the petriplate. The pure culture of the fungus was sent to Indian type culture collection center, Plant Pathology division, IARI, New Delhi for identification. The fungus was identified as sterile mycelium (ID10954.18).

Maximum (35\%) seed was infected by Aspergillus niger and $28 \%$ infection with Aspergillus flavus were found to be associated with green gram seed from Sinapali and Bhadrakh respectively. Fusarium sp. and a sterile mycelium were found to be associated with seeds to the tune of $14.5 \%$ and $45 \%$ from Bhubaneswar (OUAT farm) and Junagarh (Kalahandi) respectively (Table 5). Standard blotter and agar plate method proved to be best for the emergence of seed borne pathogen of green gram than rolled paper towel method (Table 4). Baru et al., (2007), Ali et al., (2010), Ashwini and Giri (2014), Kandhare (2014) also reported association of Aspergillus flavus, Aspergillus niger, Fusariumsp and other species of Fusarium, Rhizopus, Penicillium with the green gram seed. The current study confirmed the findings of above workers. Tak et al., (2015) found $39.32 \%$ infection of A. flavus and $15.32 \%$ infection of $A$. niger with green gram seeds.

Table.1 Percent germination and infection of different Green gram seeds collected from field

\begin{tabular}{|c|c|c|c|c|c|}
\hline \multirow{2}{*}{$\begin{array}{l}\text { Sl. } \\
\text { No }\end{array}$} & \multirow[t]{2}{*}{ Place of collection } & \multicolumn{2}{|c|}{ Without surface sterilization } & \multicolumn{2}{|c|}{ With surface sterilization } \\
\hline & & \%Germination & $\%$ Infection & $\%$ Germination & \%Infection \\
\hline 1. & Bhadrak & 61.00 & 38.25 & 68.00 & 26.25 \\
\hline 2. & Junagarh & 68.00 & 24.60 & 80.50 & 29.50 \\
\hline 3. & Titlagarh & 65.75 & 30.50 & 75.00 & 28.50 \\
\hline 4. & $\begin{array}{l}\text { Bhubaneswar } \\
\text { (OUAT farm) }\end{array}$ & 66.00 & 16.50 & 70. 00 & 15.50 \\
\hline 5. & Bhawanipatna & 64.25 & 22.25 & 69.00 & 25.50 \\
\hline 6. & Sinapali, Nuapada & 80.00 & 15.75 & 84.00 & 14. 50 \\
\hline & Mean & 67.50 & 24.64 & 74. 41 & 23.29 \\
\hline
\end{tabular}


Table.2 Percent germination and infection of different Green gram seeds collected from store

\begin{tabular}{|c|c|c|c|c|c|}
\hline \multirow{2}{*}{$\begin{array}{l}\text { Sl. } \\
\text { No }\end{array}$} & \multirow[t]{2}{*}{ Place of collection } & \multicolumn{2}{|c|}{ No surface sterilization } & \multicolumn{2}{|c|}{ Surface sterilized } \\
\hline & & $\%$ Germination & $\%$ Infection & $\%$ Germination & $\%$ Infection \\
\hline 1 & $\begin{array}{l}\text { Bhubaneswar } \\
\text { (no1 market) }\end{array}$ & 75.00 & 20.50 & 83.00 & 18.5 \\
\hline 2 & Bhadrak & 59.75 & 35.25 & 63.25 & 28.5 \\
\hline 3 & Junagarh & 70.50 & 26.50 & 78.00 & 20.25 \\
\hline 4 & Titlagarh & 64.45 & 17.50 & 80.00 & 12.5 \\
\hline 5 & Bhawanipatna & 69.75 & 27.50 & 73.50 & 23.5 \\
\hline 6 & Sinapali,Nuapada & 82.00 & 15.25 & 88.00 & 12.5 \\
\hline & Mean & 70.24 & 23.75 & 77.62 & 19. 29 \\
\hline
\end{tabular}

Table.3 Seed health evaluation by dry seed examination

\begin{tabular}{|l|c|c|c|c|c|c|c|}
\hline $\begin{array}{l}\text { Source of collection } \\
\text { of seed }\end{array}$ & $\begin{array}{c}\text { Damaged } \\
\text { Seed (\%) }\end{array}$ & $\begin{array}{c}\text { Discolour } \\
\text { ed seed } \\
(\%)\end{array}$ & $\begin{array}{c}\text { Small/ } \\
\text { undersized } \\
\text { Seeds }\end{array}$ & $\begin{array}{c}\text { Shrunken } \\
\text { seeds (\%) }\end{array}$ & $\begin{array}{c}\text { Inert } \\
\text { matter } \\
\text { plant parts } \\
\text { \&soil } \\
\text { particles }\end{array}$ & $\begin{array}{c}\text { Weed } \\
\text { seeds } \\
(\%)\end{array}$ & $\begin{array}{c}\text { Healthy } \\
\text { Seed } \\
(\%)\end{array}$ \\
\hline $\begin{array}{l}\text { Bhubaneswar } \\
\text { (No. 1 market) }\end{array}$ & 6.85 & 4.75 & 8.75 & 1.50 & - & - & 78.15 \\
\hline Bhadrak & 15.25 & 10.75 & 10.5 & 7.00 & 1.00 & 0.75 & 54.75 \\
\hline $\begin{array}{l}\text { Bhubaneswar } \\
\text { (OUAT farm }\end{array}$ & 1.25 & 8.25 & 7.50 & 2.50 & 1.25 & 0.25 & 79.00 \\
\hline Bhawanipatna & 5.25 & 4.75 & 4.50 & 2.00 & 0.25 & - & 83.25 \\
\hline Junagarh & 3.50 & 6.00 & 4.00 & 7.50 & 0.75 & - & 78.25 \\
\hline Titlagarh & 4.00 & 4.25 & 4.00 & 9.50 & 1.00 & 0.50 & 76.75 \\
\hline Sinapali, Nuapada & 2.00 & 7.50 & 5.25 & 1.00 & - & - & 84.25 \\
\hline
\end{tabular}

Table.4 Comparative efficiency of different incubation method for detection of seed mycoflora

\begin{tabular}{|l|c|c|c|c|}
\hline \multirow{2}{*}{$\begin{array}{l}\text { Place of } \\
\text { Collection }\end{array}$} & \multicolumn{4}{|c|}{ \% of seed mycoflora } \\
\cline { 2 - 5 } & Standard blotter & Agar plate & $\begin{array}{l}\text { Rolled paper } \\
\text { towel method }\end{array}$ & Mean frequency \\
\hline $\begin{array}{l}\text { Bhubaneswar } \\
\text { (no 1market }\end{array}$ & 20.5 & 47 & 24 & 30.5 \\
\hline Bhadrak & 64 & 55.5 & 50 & 56.5 \\
\hline Bhubaneswar(OUATfarm) & 30.5 & 49.5 & 60 & 46.67 \\
\hline Bhawanipatna & 29.5 & 35 & 40 & 34.83 \\
\hline Junagarh & 41 & 60 & 25 & 42 \\
\hline Titlagarh & 32.5 & 50 & 43 & 41.83 \\
\hline Sinapali,Nuapada & 35.5 & 54 & 40 & 43.16 \\
\hline Mean frequency & 36.21 & 50.14 & 40.28 & \\
\hline
\end{tabular}


Table.5 Detection of mycoflora associated with seeds of different collected varieties of Green gram in three methods

\begin{tabular}{|c|c|c|c|c|c|c|c|c|c|c|c|c|c|c|c|c|c|c|}
\hline \multirow{2}{*}{$\begin{array}{l}\text { Place of collection of } \\
\text { sample }\end{array}$} & \multicolumn{6}{|c|}{ Standard blotter method } & \multicolumn{5}{|c|}{ Agar plate method } & \multirow[b]{2}{*}{$\begin{array}{l}\text { Total } \\
\text { Frequency } \\
\%\end{array}$} & \multirow[b]{2}{*}{ A. $n$} & \multicolumn{5}{|c|}{ Rolled papertowel method } \\
\hline & A. $n$ & A. $f$ & F. sp & R. sp & SM & $\begin{array}{l}\text { Total } \\
\text { Frequency } \\
\%\end{array}$ & A. $n$ & A. $\mathrm{f}$ & F. sp & R. sp & SM & & & A. $\mathrm{f}$ & F. sp & R. sp & SM & $\begin{array}{l}\text { Total } \\
\text { Frequenc } \\
\mathrm{y} \\
\%\end{array}$ \\
\hline $\begin{array}{l}\text { Bhubaneswar } \\
\text { (1no market) }\end{array}$ & 17. 0 & 2. 0 & - & 1.5 & & 20.5 & 15.0 & 15.0 & - & & 17 & 47 & 6.0 & - & 10 & 8.0 & - & 24.0 \\
\hline $\begin{array}{l}\text { Bhadrak } \\
\text { (Main market) }\end{array}$ & 12.5 & 26.5 & - & 10.0 & 15.0 & 64 & 16.0 & 28.0 & - & 3.0 & $\begin{array}{l}18 . \\
5\end{array}$ & 55.5 & 8.0 & - & 12 & 20.0 & 10.0 & 50.0 \\
\hline $\begin{array}{l}\text { Bhubaneswar } \\
\text { (OUAT farm) }\end{array}$ & 4. 0 & 16.0 & 10.5 & - & - & 30.5 & 21.0 & 14. 0 & 14.5 & - & - & 49.5 & 2.5 & 10.5 & - & 25.0 & 22.0 & 60.0 \\
\hline $\begin{array}{l}\text { Kalahandi } \\
\text { (Bhawanipatna) }\end{array}$ & 5.0 & 10.5 & 5.5 & - & 8.5 & 29.5 & 7.5 & 10.5 & 10.0 & - & 7 & 35 & - & 10 & 5 & - & - & 40.0 \\
\hline $\begin{array}{l}\text { Kalahandi } \\
\text { (Junagah market) }\end{array}$ & 6.5 & 16.5 & 12.5 & 5.5 & - & 41 & 10.5 & 25.5 & 5.5 & 4.5 & 14 & 60 & - & 15 & - & 15.0 & 45.0 & 25.0 \\
\hline $\begin{array}{l}\text { Bolangir } \\
\text { (Titlagarh) }\end{array}$ & 18.5 & 8.5 & - & 2.0 & 3.5 & 32.5 & 15.5 & 20.0 & 2. 0 & $\begin{array}{l}13 . \\
5\end{array}$ & & 50 & 10.0 & - & - & 8.0 & 5.0 & 43.0 \\
\hline Sinapali(Nuapada) & 9.5 & 18. 5 & - & - & - & 7.5 & 20.0 & 25.0 & - & & 9.0 & 54 & 35.0 & 20 & 8 & 8.0 & - & 40.0 \\
\hline
\end{tabular}

A. n-Aspergillusniger,A. f-Aspergillusflavus,F. sp. -Fusariumsp,R. sp-Rhizoctoniasp,SM-Sterile mycelium

Table.6 Effect of seed inoculation on seed quality and health of apparently looking healthy seeds of green gram

\begin{tabular}{|c|c|c|c|c|c|c|c|c|c|}
\hline \multirow[t]{3}{*}{ Pathogens } & \multicolumn{6}{|c|}{ Seed quality parameters } & \multicolumn{3}{|c|}{ Seed health } \\
\hline & \multicolumn{2}{|c|}{ Germination $\%$} & \multirow{2}{*}{$\begin{array}{l}\text { Root } \\
\text { length } \\
(\mathrm{cm})\end{array}$} & \multirow{2}{*}{$\begin{array}{l}\text { Shoot } \\
\text { length } \\
(\mathrm{cm})\end{array}$} & \multirow{2}{*}{$\begin{array}{c}\text { Seed } \\
\text { vigour } \\
\text { index }\end{array}$} & \multirow{2}{*}{$\begin{array}{l}\text { Reduction } \\
\%\end{array}$} & \multirow{2}{*}{$\begin{array}{c}\text { Seed rot } \\
\%\end{array}$} & \multirow{2}{*}{$\begin{array}{c}\text { Root } \\
\text { symptoms } \\
\%\end{array}$} & \multirow{2}{*}{$\begin{array}{c}\text { Shoot } \\
\text { symptoms } \\
\%\end{array}$} \\
\hline & $\begin{array}{c}\text { Inoculated } \\
(\%)\end{array}$ & $\begin{array}{l}\text { Reduction } \\
(\%)\end{array}$ & & & & & & & \\
\hline Fusarium sp. & 69 & 21.59 & 6.49 & 12.00 & 1220.92 & 27.78 & 13.80 & 19.00 & 12. 25 \\
\hline Aspergillus Niger & 60 & 31.81 & 5.16 & 10.50 & 940.05 & 44. 39 & 25.25 & 24.00 & 25.50 \\
\hline Aspergillusflavus & 59 & 32.95 & 5.12 & 8.95 & 830.35 & 50.88 & 20.50 & 32.25 & 15.25 \\
\hline Sterile mycelium & 70 & 20.45 & 7.24 & 11.30 & 1300.90 & 23.05 & 17.85 & 15.25 & 10.09 \\
\hline Rhizoctoniasp & 69 & 21.59 & 7.23 & 10.20 & 1202.90 & 28.85 & 10.52 & 30.00 & 8.35 \\
\hline Control & 88 & & 9.21 & 13.41 & 1690.70 & & 5.00 & 12.00 & 4. 00 \\
\hline
\end{tabular}


Effect of seed inoculation on seed quality and health of green gram seeds

Quality parameters like germination percentage, root and shoot length were calculated for the artificially inoculated seed. The result is presented in Table 6. It was found that maximum $32.95 \%$ reduction in germination was found by Aspergillus flavus followed by Aspergillus niger (31. 81\%).

Root length and shoot length were adversely affected by all the seed borne pathogen with minimum $5.12 \mathrm{~cm}$ root length and $8.95 \mathrm{~cm}$ shoot length in Aspergillus flavus infected seed compared to $9.21 \%$ and $13.4 \%$ in control respectively. Seed vigour index was also lowest in Aspergillus flavus i.e.830.35 (50. $88 \%$ ) reduction in comparison to control.

The percentage of seed rots $(20.5 \%)$, root rot $(32.25 \%)$ were also found to be maximum in Aspergillus flavus infected green gram seed followed by Aspergillus niger. Fusarium sp, Rhizoctonia $s p$ and sterile mycelium also reduced seedling vigour index upto $27.78 \%$, $23.05 \%$, 28. $85 \%$ respectively (Table 6). Reduction of seed vigour and seed quality was also reported by workers like Ghangaoka et al., (2014), Ashwini and Giri (2014) and Kandhare (2014).

\section{References}

Ali MZ, Khan MAA, Rahaman AKMM, Ahmed M, Ahsan AFMS.2010. Study on seed quality and performance of some mungbean varieties in Bangladesh. International Journal of Experimental Agriculture, 1(2): 10-15.

Ashwini, C., Giri GK. 2014.Control of seed borne fungi in green gram and black gram through Bioagents.International Journal of Applied Biology and Pharmaceutical Technology,5(3).

Barua.JM, Hossain.M, Hossain.I, Rahman. AAMS and Sahel. Md. AT, 2007. Control of Mycoflora of Farmer's Stored Seeds of Mungbean. Asian. Journal of Plant Sciences, 6: 115-121

FAO, 2012.Grassland Index. A searchable catalogue of grass and forage FAO, Rome, Italy

Ghangaoka NM and Kshirsagar AD. 2013.Study of seed borne fungi of different legumes. Trends in life sciences, 2(1): 2319-4731.

KandharetAS,t2014.tSeedbornetFungitandtthe irtEffecttontSeedtHealthtoftGreentGram .t $\mathrm{BiosciencetDiscovery,t5(2):251-255.}$.

Kaushik CD ,Chand JN and Satyavir .1987. Seed borne nature of Rhizoctoniabataticolacausing leaf blight of mungbean.Indian Journal of Mycology and Plant Pathology,17(2): 154-157.

Neergard P.1977.Seed pathology.1and 2.The Macmillan Press Ltd.London

Tak PS, Bassi G and Singh N. 2015. Management of seed borne mycoflora of mungbean by priming with botanicals and Pseudomonas fluorescens.Plant Disease Research, 30(1 ): 34-39.

\section{How to cite this article:}

Sandhyarani Nanda, M. K. Mishra and Tensirani Pradhan, Biswajit Jena, and Lipilipsa Priyadarshinee. 2020. Mycoflora Associated with Green Gram Seeds in Odisha and their Effect on Seed Health. Int.J.Curr.Microbiol.App.Sci. 9(05): 96-103. doi: https://doi.org/10.20546/ijcmas.2020.905.009 